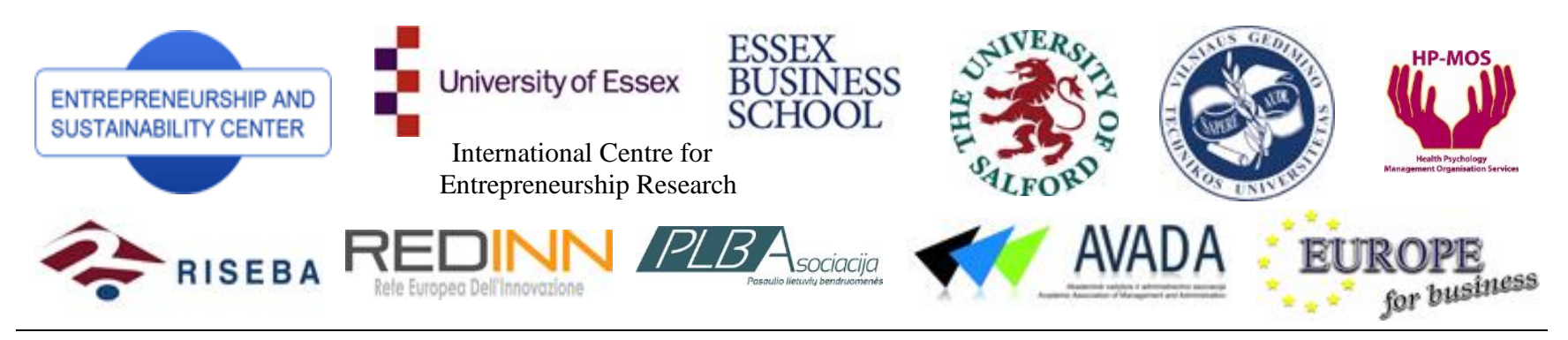

ENTREPRENEURSHIP AND SUSTAINABILITY ISSUES

ISSN 2345-0282 (online) http://jssidoi.org/jesi/aims-and-scope-of-research/

\title{
A HOLISTIC CONCEPT FOR THE SUSTAINABLE EVALUATION OF COMPANY SHARES
}

\author{
Gunnar Prause \\ Tallinn University of Technology, Estonia \\ E-mail: gunnar.prause@ttu.ee \\ Received 6 March 2014; accepted 5 June 2014
}

\begin{abstract}
Concerning the financial shares there exist a huge variety of approaches in literature. The majority of the existing concepts for the evaluation of company shares focus on financial aspects by stressing the model of present net value or of Black - Scholes in order to approximate the "financial value" of the equity to be able to calculate a fair participation of the shareholder on the company profit. The "political value" of a share, i.e. evaluation of the voting power related to a company shares, represents a rather neglected topic. An important reason for that situation is related to the fact that the voting power of shares is considered rather as a question for the SME sector than for bigger companies. In practical business life formalized methods based on correction tables are used to include the voting power into the evaluation of company shares. These approaches are rather based on historic transactions than on an analytical concept and they do not take under account the specific situation in companies. The paper will discuss a holistic approach for the evaluation of company shares based on mathematical game theory in order to develop sustainable model for integral evaluation of the "political" value and the "financial" value of company shares. The results of the mathematical approach will then be compared with the most often used methods for the evaluation of voting power of shares in business life in order to give recommendations for more realistic and fairer evaluation methods.
\end{abstract}

Keywords: evaluation of companies, voting power, game theory, mathematical models for economic problems

Reference to this paper should be made as follows: Prause, G. 2014. A holistic concept for the sustainable evaluation of company shares, Entrepreneurship and Sustainability Issues 2(1): 37-42.

DOI: http://dx.doi.org/10.9770/jesi.2014.2.1(5)

JEL Classifications: C7, G10

\section{Introduction}

In terms of financial evaluation of companies and their shares there exists a series of different approaches in scientific literature. The majority of the existing concepts is based on the models of present net value or the approach of Black - Schools focussing on the "financial value" of equity and highlighting the corresponding contribution of the shareholder to the company's profit (Leisewitz 1999; Hering 2005; Drukarczyk and Schüler 2009; Baikovs, Zarinšs 2013; Laužikas, Krasauskas 2013; Garškaitè-Milvydienè 2014). The "political value" of shares, pointing to the evaluation of the voting power related to the company's shares represents rather a neglected approach in the academic discussion even if there are studies concerning the influence of shareholders voting rights on special topics like their effect on the synergy of mergers and acquisitions or their relationship with dividend promises (Hsieh and Wang 2008; Cox and Roden 2000; Giriūnienė 2013; Giriūnas, Mackevičius 2014). Main reasons behind this are related to complicate modelling of voting power of shares and the fact that the voting power of shares or packages of shares is more interesting for the SMEs sector rather than for bigger companies. In real business life the evaluation of the voting power plays an important role in mergers where the political influence 
related to packages of shares has to be evaluated and where a fair evaluation of the political value safeguards a sustainable development after the merger. The usual procedure uses premiums, called in our case control primes, which are added as a fixed percentage to the financial value of a package of shares. The amount of the premium is oriented towards the correction tables expressing adding to the financial value of the shares, depending on the size of the share package. Generally, the control prime is neither mathematically founded nor oriented towards the specific situation of a company.

A literature review reveals that the normal range of a control prime is between $15 \%$ and $150 \%$, which is added to the inner value of the share. An empirical inside view into the height of paid control primes for the years 19901999 was done in the MergerStat Review study (2009) for 560 American transactions with a purchasing price of at least 1 Mio. \$, and an ownership share of at least 10\%. The study revealed for 1999 an annual average control prime of about $40 \%$ and a median of about $30 \%$, and a range for the control prime between minus $64.5 \%$ and plus $423.5 \%$. Surprisingly in 78 of the 560 transactions the control prime was negative, and based on these 560 transactions it was possible to elaborate the following Table 1.

Table 1. Range for the control prime

\begin{tabular}{|c|c|c|}
\hline Control prime & Number of cases & \% of cases \\
\hline$<15 \%$ & 123 & 26 \\
\hline $15-30 \%$ & 113 & 23 \\
\hline $30-45 \%$ & 97 & 20 \\
\hline $45-60 \%$ & 57 & 12 \\
\hline $60-75 \%$ & 37 & 8 \\
\hline $75-100 \%$ & 26 & 5 \\
\hline$>100 \%$ & 29 & 6 \\
\hline
\end{tabular}

Source: MergerStat Review (2009)

Even if it seems that the presented table is a little bit old, more recent results brought to light that the values of the correction table for the 1990s are in line with the more recent results of mergers, which took place about 10 years later (MergerStat Review 2009). The correction table approach is based on the statistical results from former mergers and acquisitions of bigger companies listed on the American stock exchanges bearing the weakness that they are neither reflecting the specific shareholder situation in a specific company nor they are taking into account a general mathematical approach. The paper will propose a holistic approach for the evaluation of company' shares based on the mathematical game theory trying to integrate the "political" value and the "financial" value of company's shares in order to arrive at a more reasonable evaluation method of company shares.

\section{The Banzhaf Index}

Starting point for the mathematical approach is the Penrose-Banzhaf index, called only Banzhaf index in this article, which exists in a normalised and un-normalised form, and which describes the voting power of shareholders in political systems. The pioneer work was started by Lionel Penrose in 1946 and has been reinitiated by John F. Banzhaf in 1965, yielding the normalised Banzhaf index, which will be used in this paper (Penrose 1946; Banzhaf 1965). The potential of the concept of Banzhaf for analysing the political power constellations has been proven in various cases in the political science, like in the case of the Nice Agreement of the European Union (Wilming 1995).

The basic principle of the calculation of the Banzhaf index is the analysis of majority constellations among shareholders or coalitions of shareholders, where majority means that a coalition of shareholders is able to gather enough votes to exceed the quorum for the corresponding decision. Principally, a majority depends always on the quorum, which is in correspondence with the decisions, $50 \%, 2 / 3$ or $75 \%$ of the votes, respectively. Taking $\mathrm{v}$ as the value function on the set of coalitions of shareholders of a company for a certain coalition $K$, the value $v(K)$, depending on the quorum, is 1 if $\mathrm{K}$ represents a winning coalition. Otherwise if $\mathrm{K}$ is a losing coalition the value is 0 . This approach leads to a normalised value function where the image interval for $\mathrm{v}$ is the compact interval $[0 ; 1]$ 
for all possible coalitions.

The concept of Banzhaf is based on the idea that the political power a shareholder is higher if he can turn a losing coalition into a winning one. A shareholder who is able to change a winning coalition into a losing one is called critical or pivotal shareholder for a certain coalition. By using the value function $\mathrm{v}$ for a coalition $\mathrm{K}$ the shareholder $\mathrm{i}$ is pivotal if and only if $[\mathrm{v}(\mathrm{K})-\mathrm{v}(\mathrm{K}-\{\mathrm{i}\})]=1$. For all other coalitions, i.e. where the shareholder $\mathrm{i}$ is not pivotal, the term $[\mathrm{v}(\mathrm{K})-\mathrm{v}(\mathrm{K}-\{\mathrm{i}\})]$ is always equal 0 so that these coalitions need not to be considered. With this approach to each shareholder, there can be associated a voting or a political power, which can be expressed as a percentage where the voting powers of shareholders sum up to $100 \%$. The value of the voting power of a shareholder, called the Banzhaf index for the shareholder $i$, is calculated by dividing the number of winning coalitions $\gamma$ where $i$ is critical by the sum of all winning coalitions where another shareholder than i is critical. By doing so the value of the normalised Banzhaf-Index is equal to (Holler and Illing 2006; Wilming 1995):

$$
\beta_{i}=\frac{\gamma_{i}}{\sum_{i=1}^{n} \gamma_{i}}=\frac{\sum_{i \in K ; K \subseteq W^{i}}[v(K)-v(K-\{i\})]}{\sum_{i=1}^{n} \sum_{i \in K ; K \subseteq W^{i}}[v(K)-v(K-\{i\})]}
$$

An analysis of the properties of the Banzhaf index reveals that the power of a shareholder is not an absolute value; it is always depending on the structure of the decision making institution, i.e. voting power in the sense of Banzhaf is a context sensitive construct that reflects the political situation of a shareholder relative to other shareholders and the political environment. Hence, in the literature a large number of paradoxes in the context of the Banzhaf index is well known leading to situations where an increase or decrease of shares imply opposite effects on the voting power (Felsenthal and Machover 1998). These phenomena shed light on the fact that the transactions of shares lead to changes in control primes, especially in the case where packages of shares are accumulated.

The calculation of the Banzhaf index for the different shareholders depends on the quorum and the political situation in the company, and there exist no general rules to fix a control primes for a shareholder. Usually the quorum for the majority of operative decisions is $50 \%$ plus, but even with this simplification the specification of a fair control prime is a complicated task, which will be demonstrated by the following example. Let us pretend that the company has only 3 shareholders and the quorum is $50 \%$. We will consider 3 different companies $\mathrm{X}, \mathrm{Y}$ and $\mathrm{Z}$ with the 3 shareholders $\mathrm{A}, \mathrm{B}$ and $\mathrm{C}$ where the percentage of shares, which are owned by the shareholders, is different (Table 2).

Table 2. The calculation of the Banzhaf index

\begin{tabular}{|c|c|c|c|c|}
\hline Shareholder & Company X & Company Y & Company Z & Banzhaf Index \\
\hline $\mathbf{A}$ & $1 / 3$ & $20 \%$ & $15 \%$ & $1 / 3$ \\
\hline B & $1 / 3$ & $40 \%$ & $40 \%$ & $1 / 3$ \\
\hline $\mathbf{C}$ & $1 / 3$ & $40 \%$ & $45 \%$ & $1 / 3$ \\
\hline
\end{tabular}

Source: author's calculation

The corresponding Banzhaf index based on the 50\% quorum for the different shareholders in the 3 companies are all the same, namely $1 / 3$. So the question appears how to fix a fair control prime for the 3 shareholders. The case of company $\mathrm{X}$ is easy to solve since the financial power and the political power are in line, i.e. the control prime for all shareholders is zero. More complicated are the cases of the companies $\mathrm{Y}$ and $\mathrm{Z}$ where a difference between the financial and the political power exists and where the deviation especially for shareholder $\mathrm{A}$ for company $\mathrm{Z}$ is higher than for company Y. 


\section{A Holistic Shareholder Value}

The scientific literature does not have a unique solution for the integral evaluation problem for a shareholder, taking simultaneously into account the financial and the political values of a share in order to generate a holistic value of the shareholder. One approach for the calculation of a holistic value of a shareholder can be based on the use of the financial and the political value as input factors. For the financial value we will take the percentage of package of shares of the shareholder, whereas for the political value we will take the corresponding Banzhaf index. Thus, if $\mathrm{H}$ is the holistic value of the share of a shareholder $\mathrm{i}, \mathrm{A}$ the financial value for the shareholder and $\mathrm{M}$ the voting power of the shareholder, then $\mathrm{H}_{\mathrm{i}}=\mathrm{R}(\mathrm{A}, \mathrm{M}, \mathrm{i})$ with an unknown function $\mathrm{R}$. In the sequel we will discuss different versions for the function $\mathrm{R}$. The simplest method for choosing $\mathrm{R}$ is a weighted sum of the financial value $\mathrm{A}$ and the value $\mathrm{M}$ for the voting power yielding the following equation:

$$
H=A+\alpha(M-A), \text { with } 0 \leq \alpha \leq 1 .
$$

The parameter $\alpha$ fixes the weights of the financial value A and the power index $\mathrm{M}$ of the share. The higher the parameter $\alpha$ is chosen, the higher the voting power of the share is weighted. This approach safeguards that the sum of all corrected shares of all shareholders will sum up to $100 \%$. Therefore, the holistic share value is calculated as a weighted sum of the financial and the political value of the share. As a special case appears for $\alpha=0.5$, where the weighted sum leads to an equation for $\mathrm{H}$, which is analogue to the famous practitioners formula for the evaluation of companies, which assumes that a realistic first estimation of the company value is the average of the capitalized earning value and the asset value of the company yielding in our case of the holistic shareholder value to the following equation (Peemöller 2012):

$$
H=\frac{A+M}{2} \text {, with the financial value } \mathrm{A} \text { and the voting power } \mathrm{M} \text {. }
$$

A more sophisticated way for the construction of the function $\mathrm{R}$ and the calculation of $\mathrm{H}$ is based on the Gini coefficient which represents a well-known statistical measure for the inequality within a value set of a distribution (Gini 1909 and 1912). It should be recalled that a Gini coefficient of zero expresses an equal distribution, whereas a Gini coefficient of one or $100 \%$ expresses maximal inequality among values. Mathematically the Gini coefficient is usually defined by using the Lorenz curve (Bleymüller et al. 2008). In our approach the Gini coefficient is used in a first step to calculate the inequality of the political power among the shareholders in comparison with their company shares.

In order to illustrate the idea we take our already discussed example with the three stakeholders and the three companies to calculate the Gini coefficients for the three companies X, Y and Z on the base of the initial situation (Table 3).

Table 3. Gini coefficients for the three companies X, Y and Z

\begin{tabular}{|c|c|c|c|c|}
\hline Shareholder & Company X & Company Y & Company Z & Banzhaf Index \\
\hline A & $1 / 3$ & $20 \%$ & $15 \%$ & $1 / 3$ \\
\hline B & $1 / 3$ & $40 \%$ & $40 \%$ & $1 / 3$ \\
\hline C & $1 / 3$ & $40 \%$ & $45 \%$ & $1 / 3$ \\
\hline
\end{tabular}

Source: author's calculation

Already from a first look to the table it easy to see that the Gini coefficient in company $\mathrm{X}$ is zero since the financial shares of the three shareholders are coincident with the Banzhaf index, i.e. the financial power and the political power are in line so all values are equally distributed. Another picture reveals the situation in the companies Y and $\mathrm{Z}$. The underlying value sets for the companies $\mathrm{Y}$ and $\mathrm{Z}$ which are leading to the corresponding Lorentz curve are listed in the Table 4. 
Table 4. The underlying value sets for the companies $\mathrm{Y}$ and $\mathrm{Z}$ which are leading to the corresponding Lorentz curve

\begin{tabular}{|ll|ll|}
\hline Company $\mathrm{Y}$ & \multicolumn{2}{|l|}{ Company Z } \\
$0 \%$ & 0 & $0 \%$ & 0 \\
$40 \%$ & $1 / 3$ & $45 \%$ & $1 / 3$ \\
$80 \%$ & $2 / 3$ & $85 \%$ & $2 / 3$ \\
$100 \%$ & 1 & $100 \%$ & 1 \\
\hline
\end{tabular}

Source: author

On the base of these data it is possible to calculate the Gini coefficients for company $\mathrm{Y}$ and company $\mathrm{Z}$ which leads to the results (Table 5).

Table 5. Gini coefficients for company $\mathrm{Y}$ and company $\mathrm{Z}$

\begin{tabular}{|c|c|c|}
\hline Company X & Company Y & Company Z \\
\hline 0,00 & 0,13 & 0,20 \\
\hline
\end{tabular}

Source: author's calculation

The result shows that in company $\mathrm{Z}$ the greatest deviation between the financial share and the political share appears. This deviation between the financial and the political power expressed by the Gini coefficient is now used to find a new calculation method for $\mathrm{H}$. The background idea is that if the Gini coefficient measures the integral deviation from equal distribution in form of a percentage then it will be a reasonable approach to distribute the Gini percentage as a control prime to those shareholders with a Banzhaf index higher than its financial value. If more than one shareholder exists in the company whose Banzhaf index higher than its financial value then the Gini percentage shall be distributed proportionally according to the deviation to these shareholders. For other shareholders enjoying a lower Banzhaf index than the financial value there will be no control prime. Coming back to our example with the three shareholders and the three companies there is only shareholder A in company $\mathrm{Y}$ and company $\mathrm{Z}$, who suffers under a higher Banzhaf index than the financial value, so that the full Gini percentage of $13 \%$ and $20 \%$ can be added to as a control prime to A in company $\mathrm{Y}$ and company $\mathrm{Z}$. If more than one shareholder like A would appear in a company, then the Gini percentage would be distributed among these shareholders proportionally to their deviation between the Banzhaf index and the financial value like already stated.

\section{Conclusions}

When it comes to the evaluation of shares and packages of shares of companies the scientific discussion is usually dominated by topics related to the financial value. The consideration of the political power of the shareholder in the evaluation is mainly neglected. Only in special cases like mergers and acquisition of big companies or the relationship of voting rights and dividends the political power comes into the focus and even in these cases the existing results are more of statistical nature based on historic transactions so that they do not take into account the specific company situation.

Mathematical game theory offers approaches for the evaluation of political power in institutions and a well know concept is the Penrose - Banzhaf index. The normalised version, called Banzhaf index, is a powerful concept to evaluate the voting power of shareholders. Even if the Banzhaf index depends on a fixed quorum it is possible to attribute a voting power to shareholders, which realistically reflects the political power in a certain company environment and helps so to safeguard a sustainable development after the merger.

On the basis of the Banzhaf index of a shareholder together with the financial value of its package of shares it becomes possible to propose a holistic shareholder value integrating the financial and the political power and 
turning into a unique value. The paper proposes different methods for this holistic evaluation making it possible also to offer solutions for the calculation of control primes for each size of company, including SMEs sector reflecting the specific situation of a company together with its specific institutional business environment.

\section{References}

Banzhaf, J. 1965. Weighted voting doesn't work: A mathematical analysis, Rutgers Law Review 19(2): 317-343.

Bleymüller, J.; Gehlert, G.; Gülicher, H. 2008. Statistik für Wirtschaftswissenschaftler [Statistics for Economists]. 15th edition. Verlag Vahlen.

Cox, S.; Roden, D. 2000. The Source of Value of Voting Rights and related Dividend Promises. Indiana University.

Drukarczyk, J.; Schüler, A. 2009. Unternehmensbewertung [Business evaluation]. Vahlen Verlag, München.

Felsenthal, D.; Machover, M. 1998. The measurement of voting power theory and practice, problems and paradoxes. Cheltenham.

Garškaitè-Milvydienè, K. 2014. Anti-crisis management of enterprises and possibilities of overcoming their critical condition, Entrepreneurship and Sustainability Issues 1(4): 187-203. DOI: http://dx.doi.org/10.9770/jesi.2014.1.4(1)

Gini, C. 1909. Concentration and dependency ratios (in Italian). English translation in Rivista di Politica Economica 87 (1997): $769-789$.

Gini, C. 1912. Variabilità e mutabilità [Variability and Mutability]. C. Cuppini, Bologna, 156 p. Reprinted in Memorie di metodologica statistica (Ed. Pizetti, E.; Salvemini, T). Rome: Libreria Eredi Virgilio Veschi (1955).

Giriūnas, L.; Mackevičius, J. 2014. Evaluation of frauds in public sector, Entrepreneurship and Sustainability Issues 1(3): 143-150. DOI: http://dx.doi.org/10.9770/jesi.2014.1.3(3)

Laužikas, M.; Krasauskas, A. 2013. Impacts of sustainable structural growth on the economic performance of listed companies, Entrepreneurship and Sustainability Issues 1(2): 81-91 DOI: http://dx.doi.org/10.9770/jesi.2013.1.2(2)

Baikovs, A.; Zarinšs, I. 2013. Philosophical, legal and general issues of legal liability, Entrepreneurship and Sustainability Issues 1(1): 2336. DOI: http://dx.doi.org/10.9770/jesi.2013.1.1(3)

Giriūnienè, G. 2013. Public sector's subsidies to business - suitability valuation of labor market support measures, Entrepreneurship and Sustainability Issues 1(1): 37-44. DOI: http://dx.doi.org/10.9770/jesi.2013.1.1(4)

Hering, T. 2005. Unternehmensbewertung [Business Evaluation]. Oldenbourg Verlag, Berlin.

Holler, M.; Illing, G. 2006. Einführung in die Spieltheorie [Introduction to Game Theory]. Berlin.

Hsieh, J.; Wang, Q. 2008. Shareholder Voting Rights in Mergers and Acquisitions. Georgia Institute of Technology.

Leisewitz, M.C.1999. Das Problem der Unschärfe in der Unternehmensbewertung [The problem of the uncertainty in the evaluation of businesses]. Göttingen.

Mergerstat Review. 2009. Control Premium Data 2007-2008.

Peemöller, V. 2012. Praxishandbuch der Unternehmensbewertung: Grundlagen und Methoden [Practical Guide for the Business Evaluation: Principles and Methods]. Bewertungsverfahren. Besonderheiten bei der Bewertung, NWB Verlag, Herne.

Penrose, L. 1946. The Elementary Statistics of Majority Voting, J. Royal Statistical Society 109(1): 53-57.

Wilming, C. 1995. Institutionelle Konsequenzen einer Erweiterung der EU [Institutional consequences of EU enlargement]. Baden-Baden.

Gunnar PRAUSE is Professor for International Business in Tallinn School of Economics and Business Administration (TSEBA) of Tallinn University of Technology. Research interests: International Business, Entrepreneurship \& SME - Management, Logistics, Innovation. He is Board Member of the Centre for Business Research and Development at the Department of Business Administration of TSEBA, Board Member of the Institute of Cooperative Studies at Humboldt University Berlin, Board Member of Baltic China Science Park Network. He is author of more than 100 scientific articles. 